\title{
A Rapid Microbioassay for Discovery of Novel Fungicides for Phytophthora spp.
}

\author{
Jeanne M. Kuhajek, Steven N. Jeffers, Marc Slattery, and David E. Wedge
}

First and third authors: Department of Pharmacognosy and The National Center for Natural Products Research, School of Pharmacy, The University of Mississippi, University 38677; second author: Department of Plant Pathology and Physiology, Clemson University, Clemson, SC 29734; and fourth author: U.S. Department of Agriculture-Agricultural Research Service, NPURU, The National Center for Natural Products Research, The University of Mississippi, University 38677.

Current address of J. M. Kuhajek: Landcare Research, P.O. Box 69, Lincoln 8152, New Zealand.

Accepted for publication 5 July 2002.

\begin{abstract}
Kuhajek, J. M., Jeffers, S. N., Slattery, M., and Wedge, D. E. 2003. A rapid microbioassay for discovery of novel fungicides for Phytophthora spp. Phytopathology 93:46-53.

A microbioassay was developed for the discovery of compounds that inhibit Phytophthora spp. This assay uses a 96-well format for highthroughput capability and a standardized method for quantitation of initial zoospore concentrations for maximum reproducibility. Zoospore suspensions were quantifiable between 0.7 and $1.5 \times 10^{5}$ zoospores per $\mathrm{ml}$ using percent transmittance $(620 \mathrm{~nm})$. Subsequent growth of mycelia was monitored by measuring optical density $(620 \mathrm{~nm})$ at $24-\mathrm{h}$ intervals for $96 \mathrm{~h}$. Full- and half-strength preparations of each of three media (V8 broth, Roswell Park Memorial Institute mycological broth [RPMI], and mineral salts medium) and four zoospore concentrations (10, 100, 1,000,

and 10,000 zoospores per $\mathrm{ml}$ ) were evaluated. Both full- and halfstrength RPMI were identified as suitable synthetic media for growing $P$. nicotianae, and 1,000 zoospores per $\mathrm{ml}$ was established as the optimum initial concentration. The assay was used to determine effective concentration values for $50 \%$ growth reduction $\left(\mathrm{EC}_{50}\right)$ for seven commercial antifungal compounds (azoxystrobin, fosetyl-aluminum, etridiazole, metalaxyl, pentachloronitrobenzene, pimaricin, and propamocarb). These $\mathrm{EC}_{50}$ values were compared with those obtained by measuring linear growth of mycelia on fungicide-amended medium. The microbioassay proved to be a rapid, reproducible, and efficient method for testing the efficacy of compounds that inhibit spore germination in $P$. nicotianae and should be effective for other species of Phytophthora as well. The assay requires relatively small amounts of a test compound and is suitable for the evaluation of natural product samples.
\end{abstract}

Several species in the genus Phytophthora cause diseases that result in devastating losses to a wide variety of plants. These diseases, including root and crown rots, cankers, foliar blights, and fruit rots, affect food and fiber crops, forest trees, and a variety of ornamental plants $(1,20)$. The impact of Phytophthora spp. on food and fiber production is enormous $(20,52)$. In the United States alone, crop losses attributed to these pathogens exceed several billion dollars annually (20). Worldwide, costs for chemical management of Phytophthora diseases represent over $25 \%$ of the annual fungicide market $(47,48)$. Advances in cultural practices, disease forecasting programs, and the availability of resistant cultivars have improved disease management, but fungicides remain an indispensable component of any effective disease management program (20).

Chemicals effective against Phytophthora spp. are limited. Many broad-spectrum fungicides are not effective against these organisms (15) and few alternatives are available. The development of several chemicals specifically targeting Phytophthora spp. and other oomycetes (e.g., etridiazole, metalaxyl, mefenoxam, and fosetyl-Al) has improved management of Phytophthora diseases (1). However, the rapid regeneration times and exceptional adaptability of Phytophthora spp. (6) have resulted in the development of fungicide resistance within specific pathogen populations, e.g., $P$. infestans on potatoes $(11,12,14), P$. capsici on peppers and cucurbits $(33,41,43)$, and $P$. nicotianae $(=P$. parasitica) and $P$. citricola on ornamental hosts $(16,25)$. There is potential for develop-

Corresponding author: J. M. Kuhajek

E-mail address: kuhajekj@landcareresearch.co.nz

Publication no. P-2002-1030-01R

(C) 2003 The American Phytopathological Society ment of resistance in other populations of Phytophthora spp. Given the enormous economic impact of Phytophthora diseases worldwide, discovery of new and novel chemicals to manage these pathogens is an important priority in fungicide research.

Discovery of new fungicides for the management of Phytophthora spp. relies primarily on in vivo assessment of efficacy on greenhouse-grown plants (L. D. Houseworth, Syngenta, personal communication). This method is time consuming, material and labor intensive, and requires relatively large quantities of test compounds. In vitro assays (e.g., growth or development of fungi on fungicide-amended agar medium) often supplement in vivo studies $(7,23,24,37,46)$; however, these too are tedious and relatively large scale. Although these methods are adequate for evaluating compounds derived from synthetic sources, they are unsuitable for assessing natural products and other limited quantity samples.

Natural products are a prolific source of chemical diversity and provide enormous potential for the discovery of novel biologically active compounds (56). They remain virtually untapped for plant disease management, however, primarily because initial quantities of natural product extracts and test compounds often are insufficient for evaluation using traditional bioassay methods. A need exists for an effective and efficient method to screen natural product samples for potential inhibitory activity against Phytophthora spp. and other plant pathogens.

The purpose of this study was to develop a rapid, quantitative, microscale bioassay for the discovery of novel compounds with efficacy against Phytophthora spp. In vitro assessment of Phytophthora spp. presents a challenge because the diverse life stages of these organisms are differentially sensitive to the inhibitory effects of fungicides $(7,23,24,37,46,53)$. Any single bioassay likely will miss some active compounds; however, development 
of an efficient and reproducible method for the preliminary evaluation of natural products and other samples of limited quantity is needed. The specific aims of this study were to (i) standardize initial zoospore concentrations; (ii) identify a suitable synthetic medium for quantifiable growth; (iii) determine the optimum initial zoospore concentration for the selected medium; and (iv) compare the microbioassay with the standard fungicideamended agar assay.

\section{MATERIALS AND METHODS}

Fungi. $P$. nicotianae Breda de Haan (=P. parasitica Dastur) was selected as a model species for assay development because it has a broad host range (20) and readily and consistently produces abundant quantities of zoospores in vitro. Isolates used in this study (AF016, D003, and D119) were recovered from diseased ornamental plants in South Carolina and are maintained by S. N. Jeffers in a permanent collection in the Department of Plant Pathology and Physiology, Clemson University, South Carolina. Axenic cultures of each isolate were grown in the dark at $26^{\circ} \mathrm{C}$ on V8-juice agar (V8A) (200 ml of V8 juice [Campbell Soup Co., Camden, NJ], $15 \mathrm{~g}$ of Difco Bacto agar [Difco Laboratories, Detroit], $3 \mathrm{~g}$ of $\mathrm{CaCO}_{3}$, and $800 \mathrm{ml}$ of distilled water). After 4 days, 5 -mm agar plugs from the leading edge of individual colonies were transferred into several sterile $1.5-\mathrm{ml}$ microcentrifuge tubes containing $1 \mathrm{ml}$ of sterile distilled water, and tubes were stored in the dark at $15^{\circ} \mathrm{C}(2,4)$.

Zoospore production. Zoospores were produced under aseptic conditions following a modification of the procedure reported by Chen and Zentmyer (9). Plugs from storage tubes were transferred onto V8A and incubated in the dark at $26^{\circ} \mathrm{C}$. Fifteen 5-mm agar plugs were transferred from the leading edge of a 4-day-old colony to a disposable petri dish $(60 \times 15 \mathrm{~mm})$ containing $5 \mathrm{ml}$ of sterile mineral salts solution (MSS): $3.08 \mathrm{~g}$ of $\mathrm{Ca}\left(\mathrm{NO}_{3}\right)_{2} \cdot 4 \mathrm{H}_{2} \mathrm{O}$, $1.49 \mathrm{~g}$ of $\mathrm{MgSO}_{4} \cdot 7 \mathrm{H}_{2} \mathrm{O}$, and $0.51 \mathrm{~g}$ of $\mathrm{KNO}_{3}$ in 1 liter of distilled water autoclaved for $15 \mathrm{~min}$ at $121^{\circ} \mathrm{C}$ and then supplemented with $1 \mathrm{ml}$ of chelated iron solution $(6.525 \mathrm{~g}$ of EDTA, $0.375 \mathrm{~g}$ of $\mathrm{KOH}$, and $1.245 \mathrm{~g}$ of $\mathrm{FeSO}_{4} \cdot 7 \mathrm{H}_{2} \mathrm{O}$ in $50 \mathrm{ml}$ of distilled water and filtersterilized through a $0.2-\mu \mathrm{m}$ Millipore membrane filter). Dishes were placed under continuous light at $20^{\circ} \mathrm{C}$ (i.e., approximately $15 \mathrm{~cm}$ beneath four fluorescent tubes $[17 \mathrm{~W}$, cool white, $85 \pm$ $\left.5 \mu \mathrm{mol} \mathrm{m} \mathrm{m}^{-2} \mathrm{~s}\right)$ to induce sporangium production. At $24 \mathrm{~h}$, the salt solution was replaced with fresh solution. After $48 \mathrm{~h}$, the salt solution was removed and the plugs were rinsed three times with $5 \mathrm{ml}$ of sterile distilled water and covered with $5 \mathrm{ml}$ of the same. To induce synchronous cleavage and release of zoospores, dishes were placed at $4^{\circ} \mathrm{C}$ for $20 \mathrm{~min}$ and then moved back under lights at $20^{\circ} \mathrm{C}$ for $3 \mathrm{~h}$. The zoospore suspension from each dish was transferred to a 15-ml conical tube and left undisturbed for $5 \mathrm{~min}$ to allow mycelium fragments and other heavy particles to settle. The upper $4 \mathrm{ml}$, containing free-swimming zoospores, was transferred to a second tube and vortexed for $70 \mathrm{~s}$ to encyst zoospores. Zoospores were stained with rose bengal (300 ppm in aqueous solution) to verify viability; the number of colorless (viable) zoospores was counted with a hemacytometer (26). Concentrations of viable zoospores typically were around $1 \times 10^{5}$ zoospores per ml.

Suspensions of encysted nonstained zoospores were adjusted to the linear range of transmittance with sterile distilled water and standardized to a specified zoospore concentration by dilution with medium. The linear range of transmittance was determined by plotting a regression line between percent transmittance and zoospore concentration. A stock zoospore suspension from isolate AF016 was diluted serially with sterile distilled water to yield 10 concentrations. After thorough mixing, each suspension was enumerated with a hemacytometer and evaluated for percent transmittance at $620 \mathrm{~nm}$ with a spectrophotometer (slit width of $3 \mathrm{~nm}$; Shimadzu UV-3101PC; Shimadzu Scientific Instruments, Columbia, MD); counts and readings were conducted three times for each sample to yield a mean value. Means were pooled from three separate experiments repeated in time.

Evaluation of media. Growth of the three isolates of $P$. nicotianae was evaluated in full- and half-strength preparations of two synthetic and one natural liquid media. Synthetic media were Roswell Park Memorial Institute mycological broth (RPMI: $16.2 \mathrm{~g}$ of RPMI 1640 medium per liter, with L-glutamine and $\mathrm{pH}$ indicator and without bicarbonate [Life Technologies, Grand Island, NY]) and mineral salts medium (MSM: MSS amended with $20 \mathrm{~g}$ of Dglucose per liter and $0.8 \mathrm{mg}$ of thiamin per liter). The natural medium was clarified V8 broth (V8B: $200 \mathrm{ml}$ of clarified V8 juice [i.e., centrifuged at $10,000 \mathrm{rpm}$ for $10 \mathrm{~min}$ and filtered through Miracloth] and $800 \mathrm{ml}$ of deionized distilled water). All media were buffered with 3-( $N$-morpholino) propanesulfonic acid (MOPS) buffer (34.5 g/liter; Sigma Chemical Co., St. Louis), adjusted to $\mathrm{pH} 7.0 \pm 0.1$ at $25^{\circ} \mathrm{C}$ with $1.0 \mathrm{~N} \mathrm{NaOH}$, and filter sterilized through a $0.2-\mu \mathrm{m}$ Millipore membrane filter (38) to remove particulates that could interfere with photometric growth evaluation.

Each medium was dispensed into 14 replicate wells of a 96-well flat-bottom microtiter plate (Nunc MicroWell, untreated; Roskilde, Denmark). Each test well received $100 \mu \mathrm{l}$ of medium and $100 \mu \mathrm{l}$ of zoospore suspension at 1,000 zoospores per $\mathrm{ml}$ for a total well volume of $200 \mu \mathrm{l}$ (5) and a final zoospore concentration of 500 per $\mathrm{ml}$ (=100 per well). Sterility control wells for each preparation contained $200 \mu \mathrm{l}$ of medium only. Microtiter plates were covered and placed in the dark at $26^{\circ} \mathrm{C}$. Growth was evaluated photometrically at $620 \mathrm{~nm}$ (42) by measuring optical density in each well at 24-h intervals for $96 \mathrm{~h}$ with a microplate photometer (SpectraCount; Packard Instrument Co., Meriden, CT). All values were corrected for optical density at time zero, and experiments were conducted four times in time for each isolate.

Evaluation of zoospore concentration. Growth in half-strength RPMI was evaluated for four zoospore concentrations: 10, 100, 1,000 , and 10,000 zoospores per ml. Separate stock zoospore suspensions from each of the three isolates were standardized to $1 \times$ $10^{4}$ zoospores per $\mathrm{ml}$ and were adjusted using a 10-fold serial dilution to the desired zoospore concentrations. Adjusted zoospore suspensions were dispensed in $100-\mu \mathrm{l}$ aliquots into 21 replicate wells of a 96-well microtiter plate and diluted with $100 \mu$ of halfstrength RPMI. Sterility and growth were evaluated as described previously, and experiments were conducted three times in time for each isolate.

Evaluation of antifungal compounds. Technical grade active ingredients (a.i.) of six commercially available fungicides effective against Phytophthora spp. were evaluated: azoxystrobin (94.7\% a.i.; Syngenta Crop Protection, Greensboro, NC), copper hydroxide (100\% a.i.; Chem Service, West Chester, PA), etridiazole (99.5\% a.i.; Chem Service), fosetyl-Al (>90\% a.i.; Chem Service), metalaxyl (99\% a.i.; Chem Service), and propamocarb (99\% a.i.; Chem Service). Two broad-spectrum antifungal compounds with limited efficacy against Phytophthora spp. also were included: pentachloronitrobenzene (PCNB; 99\% a.i.; Chem Service) and pimaricin (95\% a.i.; Chem Service). Chemicals were stored in a desiccator at $4^{\circ} \mathrm{C}$ in the dark to maintain and preserve fungicide activity. Sixty milligrams of each chemical was dissolved in $300 \mu \mathrm{l}$ of sterile distilled water (copper hydroxide and metalaxyl), 95\% ethanol (fosetyl-Al), or dimethylsulfoxide (DMSO; all others), and diluted with sterile distilled water to yield suspensions of $40 \mathrm{mg}$ of a.i. per $\mathrm{ml}$ ( $90 \%$ a.i. was used for fosetyl-Al). At the volumes added, ethanol and DMSO had no effect on growth relative to controls. Serial dilutions were made in sterile distilled water to obtain six stock suspensions for each chemical at 10, 5, 1, $0.5,0.1$, and $0.05 \mathrm{mg}$ of a.i. per ml. One hundred microliters of each stock suspension was diluted with $400 \mu \mathrm{l}$ of half-strength RPMI and dispensed into test wells. Each test well received $100 \mu \mathrm{l}$ of a chemical concentration and $100 \mu \mathrm{l}$ of zoospore suspension (1,000 zoospores per $\mathrm{ml})$ in half-strength RPMI. Growth control wells contained $100 \mu \mathrm{l}$ of half-strength RPMI and $100 \mu \mathrm{l}$ 
of zoospore suspension; treatment control wells contained $100 \mu \mathrm{l}$ of a chemical concentration and $100 \mu \mathrm{l}$ of medium without zoospores; sterility controls contained $200 \mu \mathrm{l}$ of medium only. Final test concentrations were $1,000,500,100,50,10$, and $5 \mu \mathrm{g}$ of a.i. per ml. For metalaxyl and etridiazole, concentrations of 1.0, 0.5, $0.1,0.05,0.01$, and $0.005 \mu \mathrm{g}$ of a.i. per $\mathrm{ml}$ also were evaluated. All assays included three replicate wells for each chemical concentration. Microtiter plates were incubated as previously described, and growth was evaluated at $48 \mathrm{~h}$. Percent growth was calculated by dividing the corrected optical density readings of each well by the mean corrected optical density of growth control wells. Each experiment was conducted six times in time per isolate.

Amended agar method. Mycelium-based agar amendment was selected as a control for comparative purposes because it is commonly employed for screening compounds against species of Phytophthora. Several 125-ml Erlenmeyer flasks, each containing $45 \mathrm{ml}$ of corn meal agar (CMA; Difco Laboratories), were autoclaved and cooled to approximately $55^{\circ} \mathrm{C}$. The CMA was amended with $5 \mathrm{ml}$ of a fungicide stock suspension to produce the same final concentrations as those evaluated in the microbioassay. Ethanol and DMSO had no effect on growth at the concentrations evaluated; control flasks received $5 \mathrm{ml}$ of sterile distilled water. Media were dispensed in $4.5-\mathrm{ml}$ aliquots into disposable petri dishes $(60 \times 15 \mathrm{~mm})$. Once the media solidified, a 5 -mm agar plug from the margin of a 4-day-old V8A colony was placed in the center of each dish. Three replicate dishes were used for each fungicide concentration and unamended control. Cultures were incubated in the dark at $26^{\circ} \mathrm{C}$. After 4 days, diameters of individual colonies were measured. Percent growth was calculated by subtracting the diameter of the agar plug $(5 \mathrm{~mm})$ from the diameter of each colony and dividing by the mean diameter of the unamended control colonies. These assays were conducted twice in time for each of the three isolates.

Statistical analysis. The regression value $\left(R^{2}\right)$ for the standardization of zoospore concentration was calculated with the regression function in Excel 7.0 (Microsoft Corporation, Redmond,

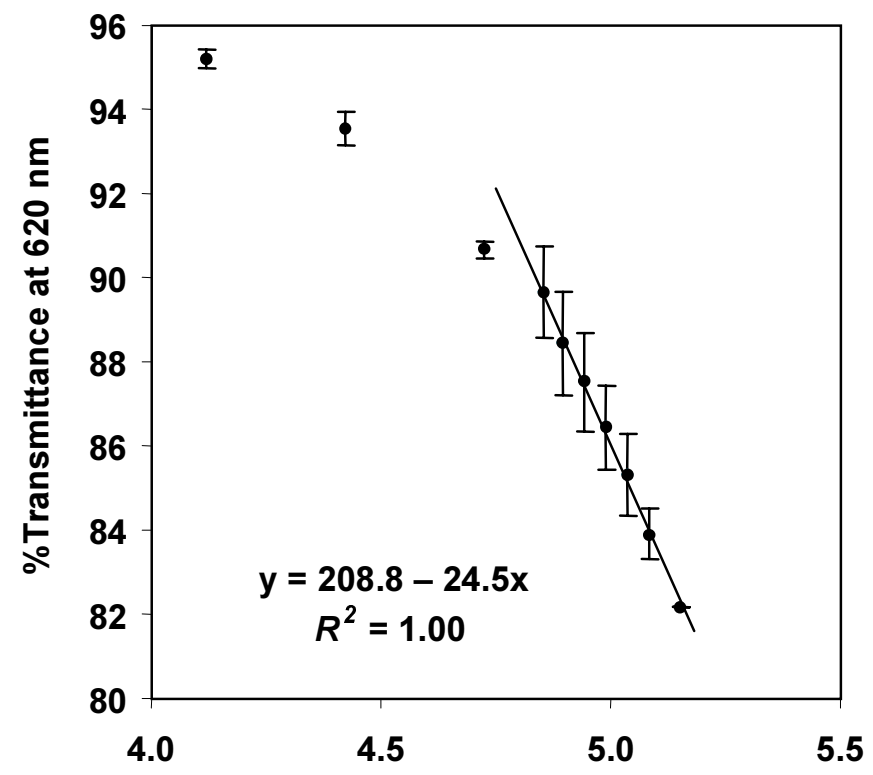

$\log _{10}$ zoospore concentration

Fig. 1. Regression line for spectrophotometric quantitation of zoospore suspensions of Phytophthora nicotianae isolate AF016. Each of three replicate stock suspensions was diluted serially with sterile distilled water to yield 10 concentrations. The resulting suspensions were enumerated with a hemacytometer, and evaluated for percent transmittance at $620 \mathrm{~nm}$. A linear relationship was found between 0.7 and $1.5 \times 10^{5}$ zoospores per ml. Data are means from the three replicates; error bars are \pm 1 standard deviation.
WA). Analyses of medium, zoospore concentration, and effective concentration values for $50 \%$ growth reduction $\left(\mathrm{EC}_{50}\right)$ were performed using StatView, version 5.0.1 (SAS Institute, Cary, NC). Log-transformed growth measurements in medium and zoospore concentration experiments were compared at 24, 48, 72, and $96 \mathrm{~h}$ by two-way analysis of variance (ANOVA) with isolate and either concentration or medium as random effects (50). Growth dynamics at each zoospore concentration were assessed by two-way ANOVA with isolate and time as random effects. $\mathrm{EC}_{50}$ values predicted by the microtiter and amended agar assays were calculated by fitting a dose-response function to a logistic model $(3,8,58)$. Log-transformed $\mathrm{EC}_{50}$ values from the two assays were compared by a separate two-way ANOVA for each fungicide with isolate and assay fixed. The main effects in all variance analyses were compared by Fisher's protected least significant difference tests with $P=0.05$ (50). Differences in $\mathrm{EC}_{50}$ values predicted by the two assays for individual isolates were evaluated with unpaired $t$ tests.

\section{RESULTS}

Standardization of zoospore concentrations. To establish a spectrophotometric method for determining zoospore concentration, a regression line for transmittance versus $\log _{10}$ zoospore concentration was plotted for concentrations between 0.15 and $1.5 \times 10^{5}$ zoospores per ml (Fig. 1). Percent transmittance was a more sensitive measure of concentration differences than was optical density at the zoospore concentrations evaluated (J. M. Kuhajek, unpublished data). A linear relationship was found in the range of 0.7 to $1.5 \times 10^{5}$ zoospores per ml or 82 to $90 \%$ transmittance $\left(R^{2}=1.00\right)$. At concentrations below $0.7 \times 10^{5}$ zoospores per $\mathrm{ml}$ (i.e., greater than $90 \%$ transmittance), transmittance measurements were found to overestimate actual zoospore concentrations. At the highest concentration evaluated, $1.5 \times 10^{5}$ zoospores

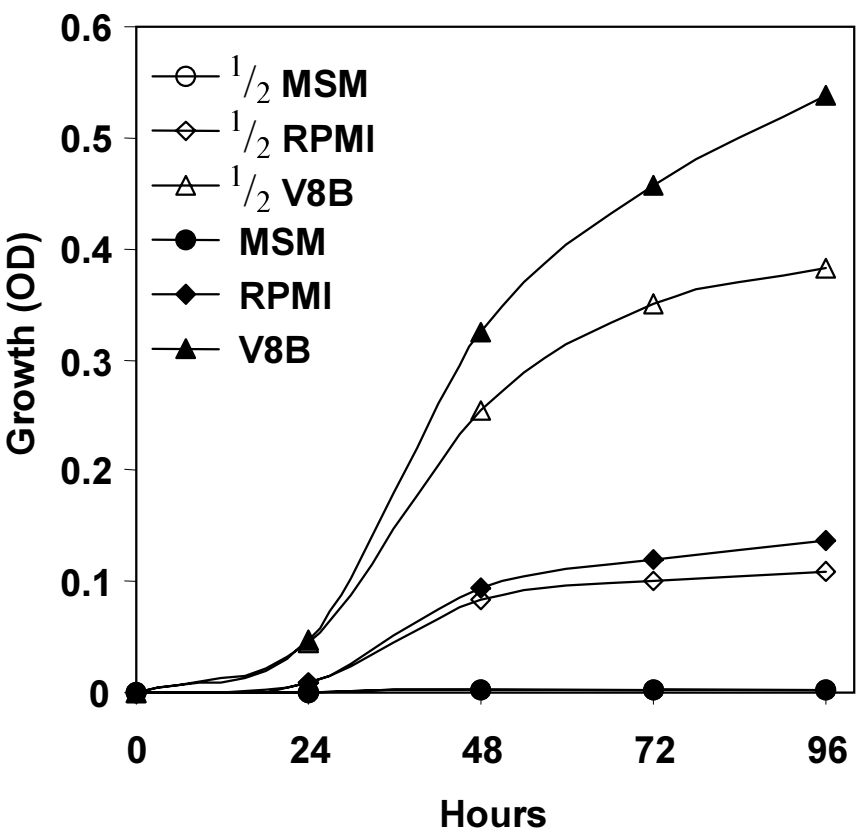

Fig. 2. Growth of Phytophthora nicotianae in full- and half-strength preparations of three liquid media at $26^{\circ} \mathrm{C}$. A suspension of zoospores $\left(1 \times 10^{3} \mathrm{zoo}-\right.$ spores per $\mathrm{ml}$ ) was added to each medium and growth was monitored at 24-h intervals for $96 \mathrm{~h}$ by measuring optical density (OD) at $620 \mathrm{~nm}$. All values are corrected for OD at time zero. Data are pooled means of three isolates in four experiments. Growth curves for full- and half-strength mineral salts medium overlap. Results from statistical analyses are shown is Table 1. Media are as follows: V8B (V8 broth), 1/2 V8B (half-strength V8B), RPMI (Roswell Park Memorial Institute mycological broth), 1/2 RPMI (halfstrength RPMI), MSM (mineral salts medium), and 1/2 MSM (half-strength MSM). 
per $\mathrm{ml}$, the relationship between transmittance and zoospore number remained linear; however, higher concentrations were undesirable because a large dilution would be required to yield the desired standardized zoospore concentration of $1 \times 10^{4}$ zoospores per ml. Therefore, a concentration of $1.5 \times 10^{5}$ zoospores per $\mathrm{ml}$ was considered the upper limit of the useful linear range.

Selection of a suitable synthetic medium. To identify an appropriate medium for the assay, growth of standardized concentrations of zoospores from three isolates of $P$. nicotianae was evaluated in full- and half-strength preparations of two synthetic and one natural medium (Fig. 2). The isolates grew in RPMI and V8B, but not in MSM; growth in both full- and half-strength MSM was nearly undetectable over the entire evaluation period (optical density of $\leq 0.003$; Fig. 2). In the remaining preparations, growth was photometrically quantifiable by $24 \mathrm{~h}$ and differed depending on medium (Table 1). Growth at each 24-h interval was superior $(P<0.01)$ in both V8 media compared with the two RPMI media (Fig. 2). Supplementing any of the tested media with additional $\mathrm{Ca}^{++}$(in the form of $\mathrm{CaCl}_{2}$ ) resulted in suppression of growth (J. M. Kuhajek, unpublished data). Growth was similar $(P=0.55)$ in both RPMI and half-strength RPMI throughout the 96 h (Fig. 2). Therefore, both full- and half-strength RPMI were identified as suitable synthetic media for zoospore germination and subsequent mycelium growth of $P$. nicotianae.

Optimum zoospore concentration. The optimum zoospore concentration for initiating growth in half-strength RPMI was determined by testing growth dynamics at four different initial zoospore concentrations (Fig. 3). Growth at the four concentrations was similar at $24 \mathrm{~h}$ but differed at 48, 72, and $96 \mathrm{~h}$ (Table 2). Growth at $48 \mathrm{~h}$ was significantly different at each zoospore concentration tested and was greater at higher concentrations $(P<$ 0.01 ). By $72 \mathrm{~h}$, however, growth at 100, 1,000, and 10,000 zoospores per ml was similar $(P>0.41)$ and greater than growth at 10 zoospores per $\mathrm{ml}(P<0.01)$. A lag phase of at least $24 \mathrm{~h}$ was observed at each concentration, after which growth increased steadily to 72 h (Fig. 3; $P<0.01$ ), except with 10,000 zoospores per $\mathrm{ml}$. At this high concentration, growth reached a plateau between 48 and $72 \mathrm{~h}(P=0.08)$ and thus was too rapid for reliable assessment using optical density. By 96 h, growth had leveled off for all concentrations except 10 zoospores per ml. A concentration of 1,000 zoospores per ml provided the most rapid and reliable growth under the bioassay conditions evaluated. At this concentration, photometric growth assessment was ideal at $48 \mathrm{~h}$ (Fig. 3).

Comparison of microtiter and amended agar assays. $\mathrm{EC}_{50}$ values predicted by the microbioassay and the amended agar assay for each of the eight antifungal compounds were compared by two-way ANOVA (Table 3 ). $\mathrm{EC}_{50}$ values differed significantly between the two assay methods for seven of the compounds; propamocarb was the only compound for which $\mathrm{EC}_{50}$ values were similar. However, significant isolate by assay interactions occurred for three of the eight compounds-azoxystrobin, copper hydroxide, and pimaricin. For these compounds, $\mathrm{EC}_{50}$ values were compared for each individual isolate and significant differences between the assays occurred for only one of the three isolates. In each case, $\mathrm{EC}_{50}$ values were greater using the microbioassay; differences between the assay methods were $53 \mu \mathrm{g} / \mathrm{ml}$ for copper hydroxide, $74 \mu \mathrm{g} / \mathrm{ml}$ for azoxystrobin, and $102 \mu \mathrm{g} / \mathrm{ml}$ for pimaricin. $\mathrm{EC}_{50}$ values for three of the remaining four compounds were also greater using the microbioassay; these differences were $104 \mu \mathrm{g} / \mathrm{ml}$ for fosetyl-Al and $1,000+\mu \mathrm{g} / \mathrm{ml}$ for both etridiazole and metalaxyl. PCNB was the only compound with greater $\mathrm{EC}_{50}$ values using the amended agar assay; $\mathrm{EC}_{50}$ values for $\mathrm{PCNB}$ were greater by $1,061 \mu \mathrm{g} / \mathrm{ml}$ with the amended agar assay compared with the microbioassay.

\section{DISCUSSION}

In this investigation, we have developed a standardized microscale bioassay for evaluating the efficacy of antifungal compounds against $P$. nicotianae. Whereas any one bioassay likely will miss some active compounds, the microbioassay provides a reproducible, quantitative procedure for rapidly testing small quantities of sample. The assay is useful for screening both natural and synthetic compounds and mixtures, including natural product extracts (32), and should be useful with other species of Phytophthora.

The standardization of methodology is critical to the reproducibility of any quantitative bioassay (22). Lazarovitis (34) demon-

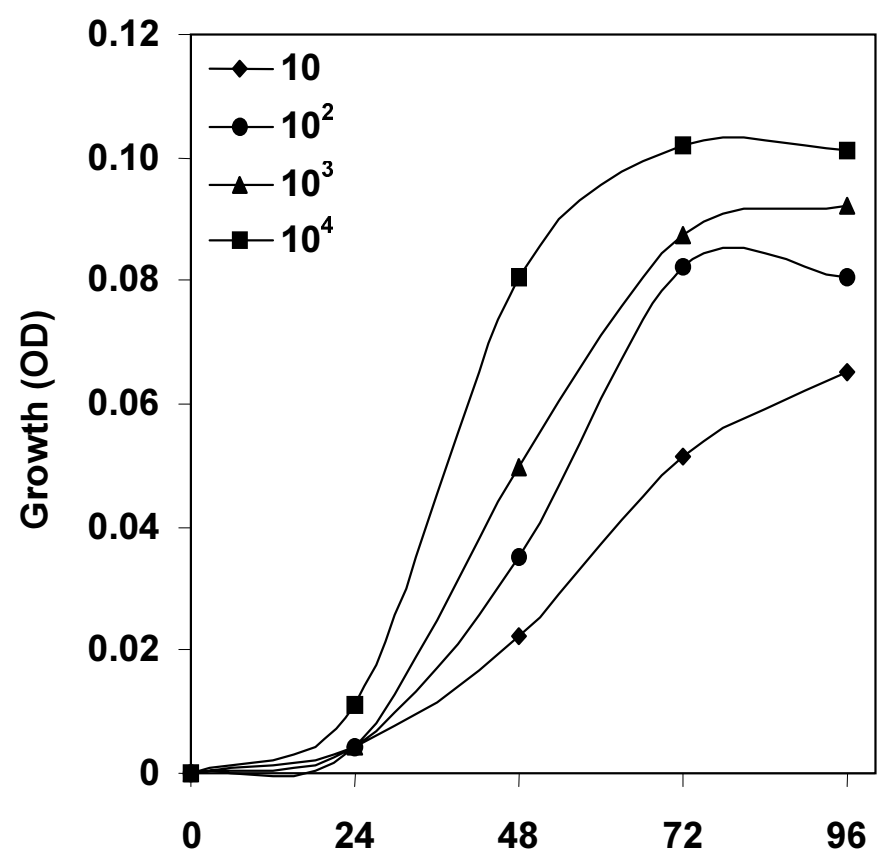

Fig. 3. Growth of Phytophthora nicotianae from four initial zoospore concentrations $\left(10,10^{2}, 10^{3}, 10^{4}\right.$ zoospores per $\left.\mathrm{ml}\right)$ at $26^{\circ} \mathrm{C}$ in half-strength Roswell Park Memorial Institute mycological broth. Growth was monitored by measurement of optical density (OD) at $620 \mathrm{~nm}$ at 24-h intervals for $96 \mathrm{~h}$. All values are corrected for OD at time zero. Data are pooled means of three isolates in three experiments. Results from statistical analyses are shown in Table 2.

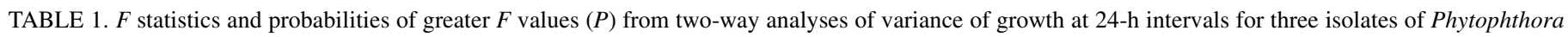
nicotianae in full- and half-strength preparations of two different media ${ }^{a}$

\begin{tabular}{|c|c|c|c|c|c|c|c|c|c|}
\hline \multirow[b]{2}{*}{ Factor $^{\mathrm{b}}$} & \multirow[b]{2}{*}{$\mathrm{df}^{\mathrm{c}}$} & \multicolumn{2}{|c|}{$24 \mathrm{~h}$} & \multicolumn{2}{|c|}{$48 \mathrm{~h}$} & \multicolumn{2}{|c|}{$72 \mathrm{~h}$} & \multicolumn{2}{|c|}{$96 \mathrm{~h}$} \\
\hline & & $F$ & $P$ & $F$ & $P$ & $F$ & $P$ & $F$ & $P$ \\
\hline Isolate & 2 & 0.98 & 0.43 & 27.78 & $<0.01$ & 49.18 & $<0.01$ & 75.19 & $<0.01$ \\
\hline Medium & 3 & 11.53 & $<0.01$ & 152.78 & $<0.01$ & 240.44 & $<0.01$ & 421.05 & $<0.01$ \\
\hline Isolate-medium & 6 & 2.08 & 0.08 & 0.54 & 0.78 & 0.51 & 0.80 & 0.36 & 0.90 \\
\hline
\end{tabular}

a Data for these analyses are shown in Figure 2.

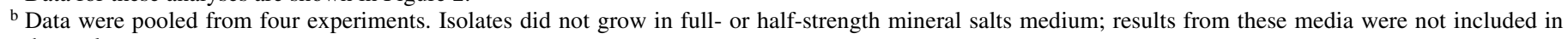
the analyses.

${ }^{c}$ Degrees of freedom. 
strated that zoospore concentration significantly influenced the sensitivity of $P$. sojae to fungicide treatment; different concentrations resulted in inconsistent $\mathrm{EC}_{50}$ values. The assay reported here incorporates a standardized procedure for preparation of zoospore suspensions, a suitable synthetic growth medium, and an optimized initial concentration of zoospores.

Zoospore suspensions of $P$. nicotianae were measured reliably within a useful concentration range for preparation of initial zoospore suspensions using percent transmittance. The concentration of zoospore suspensions typically is determined with a hemacytometer $(7,23,24,46)$; however, this method of quantitation can produce variable results and can be laborious, especially when working with multiple isolates and replicate subsamples. In contrast, spectrophotometry is rapid and reliable $(21,44,57)$. Because Phytophthora spp. do not produce conidia like many fungi, the selection of a suitable propagule for a microbioassay was challenging. A suspension of homogenized mycelium fragments was considered but quickly deemed unsuitable for three reasons. First, a suspension of fragmented mycelium results in a heterogeneous suspension and subsequently a high standard deviation in optical density values (5). Second, members of the genus Phytophthora are coenocytic with few cellular divisions in actively growing hyphae; therefore, homogenization resulted in inconsistent viability among propagules (J. M. Kuhajek, unpublished data). Third, zoospores are considered the primary infective propagule for $P h y$ tophthora spp. (17) and thus are a more appropriate assay target than mycelium.

Growth from zoospores was superior in the natural medium, V8B, compared with the two synthetic media evaluated. Similar results were reported by Luo et al. (35). However, an undefined, natural medium is undesirable for sensitive bioassays due to variability in batch-to-batch composition. To ensure maximum assay reproducibility, a completely synthetic, chemically defined medium should be used for sensitive bioassays (38). Growth requirements for most species of Phytophthora are relatively simple: calcium, thiamin $(0.2$ to $1.0 \mathrm{mg} / \mathrm{liter})$, several inorganic salts, and a suitable source of nitrogen and carbohydrates (20). A number of synthetic media have been reported to support growth of Phytophthora spp. (20) and many probably are suitable for a microtiter format. For maximum efficiency, a medium with minimal preparation time and few individual ingredients was desired. The most obvious choice was the MSS used for zoospore production amended with a carbohydrate source and a small amount of thiamin. Under the conditions evaluated however, neither full- nor half-strength preparations of this medium supported quantifiable growth of $P$. nicotianae. Alternatively, a commercially available, somewhat more complex medium, RPMI, was selected because it is readily available, simple to prepare, and has been recommended as the standard test medium for several other fungi $(38,39,57)$. In the microbioassay, buffered RPMI supported adequate growth of P. nicotianae. Although a 50\% dilution of V8B resulted in significantly less growth, no significant difference was observed when RPMI was diluted to half-strength. Because use of a diluted medium significantly reduces the expense of an assay, half-strength RPMI was selected as the medium of choice for the microbioassay.
The optimum initial concentration of zoospores for growth in half-strength RPMI was 1,000 zoospores per ml, which resulted in a final concentration of 500 zoospores per $\mathrm{ml}$ in each microtiter well. Concentrations previously employed in zoospore experiments have been similar $(7,24)$ or higher, i.e., $1.5 \times 10^{4}$ zoospores per ml (46). In our experiments, growth was superior at the highest concentration evaluated, 10,000 zoospores per ml. At this concentration, however, logarithmic growth was comparatively brief and explosive. For maximum reproducibility of bioassay results, evaluation must occur during the logarithmic phase of growth; growth during this phase should be moderately rapid and substantial at the time of evaluation. Evaluation of growth using an initial concentration of 1,000 zoospores per ml was possible at $48 \mathrm{~h}$.

$\mathrm{EC}_{50}$ values predicted by the microbioassay and the agar amendment assay were similar for only one of the fungicides tested, propamocarb. However, $\mathrm{EC}_{50}$ values predicted by the two methods differed by less than $105 \mu \mathrm{g} / \mathrm{ml}$ for four of the compounds-azoxystrobin, copper hydroxide, fosetyl-Al, and pimaricin. When differences occurred, $\mathrm{EC}_{50}$ values usually were greater in the microtiter assay. These differences, in part, reflect the superior sensitivity of the microtiter format. The amended agar method measures linear mycelium extension and does not take into account spore germination or colony density. The microbioassay, however, incorporates both zoospore germination and mycelium growth and measures three-dimensional growth of mycelia. $\mathrm{EC}_{50}$ values predicted by the microbioassay were consistent with previous reports for all antifungal agents tested except PCNB and pimaricin $(7,23,24,29,37,53,55)$.

$\mathrm{PCNB}$, or quintozene, is a broad-spectrum organochlorine fungicide and often is used in selective media for isolation of Phytophthora spp. (20,54). Concentrations of $100 \mu \mathrm{g} / \mathrm{ml}$ typically are used without detriment $(20,55)$. Although effective against many fungus species with chitin cell walls, including many Basidiomycetes and some Ascomycetes, PCNB is virtually inactive against Phytophthora spp., which lack chitin (36). Results from the microbioassay ostensibly indicate that PCNB was one of the more active fungicides evaluated. These results are unexpected given the extensive precedence in the literature for the uncompromised isolation and growth of many species of Phytophthora in the presence of PCNB $(20,54)$. Because growth was measured indirectly using optical density, the observed activity could be attributable to the combined low aqueous solubility of PCNB and the potential dissolution of the compound in the presence of $P$. nicotianae. In all replicate analyses, $\mathrm{EC}_{50}$ values for $\mathrm{PCNB}$ were similar to the concentration at which precipitation of this compound was visually apparent. Dissolution of PCNB concurrent with increasing mycelium growth would result in a relatively static optical density reading and thus the false identification of inhibitory activity, as was observed.

Like PCNB, pimaricin, a polyene antibiotic, is routinely used in selective media for the isolation of species of Phytophthora (1820,40,54,55). Phytophthora spp. lack endogenous $\beta$-hydroxy sterols and thus are resistant to the inhibitory effect of polyenes $(31,40)$. Spore germination, however, is inhibited at concentrations of $100 \mu \mathrm{g} / \mathrm{ml}$ and partial inhibition of germination occurs at lower concentrations $(40,55) . \mathrm{EC}_{50}$ values predicted for pimaricin

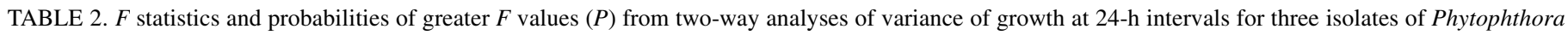
nicotianae at four initial zoospore concentrations ${ }^{\mathrm{a}}$

\begin{tabular}{|c|c|c|c|c|c|c|c|c|c|}
\hline \multirow[b]{2}{*}{ Factor $^{\mathrm{b}}$} & \multirow[b]{2}{*}{$\mathrm{df}^{\mathrm{c}}$} & \multicolumn{2}{|c|}{$24 \mathrm{~h}$} & \multicolumn{2}{|c|}{$48 \mathrm{~h}$} & \multicolumn{2}{|c|}{$72 \mathrm{~h}$} & \multicolumn{2}{|c|}{$96 \mathrm{~h}$} \\
\hline & & $F$ & $P$ & $F$ & $P$ & $F$ & $P$ & $F$ & $P$ \\
\hline Isolate & 2 & 1.30 & 0.34 & 27.25 & $<0.01$ & 33.28 & $<0.01$ & 125.96 & $<0.01$ \\
\hline Concentration & 3 & 1.60 & 0.29 & 13.62 & $<0.01$ & 7.24 & $<0.01$ & 11.57 & $<0.01$ \\
\hline Isolate-concentration & 6 & 1.57 & 0.20 & 1.77 & 0.45 & 2.51 & 0.05 & 1.00 & 0.45 \\
\hline
\end{tabular}

${ }^{a}$ Data for these analyses are shown in Figure 3.

b Data were pooled from three experiments.

c Degrees of freedom. 
by the microtiter and amended agar assays were similar for two of the three isolates and differed by only $102 \mu \mathrm{g} / \mathrm{ml}$ for the third isolate. Similarity in the results of the two assays presumably reflects the sensitivity of the microbioassay to low levels of zoospore germination and initial growth.

Azoxystrobin is a broad-spectrum fungicide that primarily targets spore germination through inhibition of mitochondrial respiration (27). Matheron and Porchas (37) reported an $\mathrm{EC}_{50}$ value of $256 \mu \mathrm{g} / \mathrm{ml}$ for inhibition of zoospore germination of one isolate of $P$. nicotianae from citrus by azoxystrobin; $\mathrm{EC}_{50}$ values for azoxystrobin determined by our microbioassay were similar. Matheron and Porchas (37) also reported an $\mathrm{EC}_{50}$ value of $>3,000 \mu \mathrm{g} / \mathrm{ml}$ when azoxystrobin was tested for inhibition of mycelium growth of $P$. nicotianae. In the amended agar assay in this study, $\mathrm{EC}_{50}$ values for azoxystrobin ranged from 56 to $165 \mu \mathrm{g} / \mathrm{ml}$ for inhibition of mycelium growth of three isolates of $P$. nicotianae from ornamental crops. Reasons for the difference between the results of the two studies are not known.

In contrast to azoxystrobin, both metalaxyl and etridiazole are potent inhibitors of mycelium growth. $\mathrm{EC}_{50}$ values previously reported for metalaxyl against $P$. nicotianae range from 0.15 to $0.38 \mu \mathrm{g} / \mathrm{ml}$ $(10,24,37,51)$. Chan and Kwee (7) obtained similar values for etridiazole against $P$. palmivora (i.e., 0.001 to $0.21 \mu \mathrm{g} / \mathrm{ml}$ ). Higher concentrations were required for $50 \%$ inhibition of zoospore germination, i.e., $280 \mu \mathrm{g} / \mathrm{ml}$ for metalaxyl (37) and 10 to $70 \mu \mathrm{g} / \mathrm{ml}$ for etridiazole (7). In this study, results from the agar amendment assay were consistent with these other reports, but all three isolates of $P$. nicotianae tested were insensitive to both compounds in the microbioassay. A probable explanation for the low activity of these fungicides in the microbioassay lies in their mechanisms of action. Metalaxyl inhibits ribosomal RNA synthesis (13). Because intact zoospores contain sufficient ribosomes for germ tube formation, metalaxyl becomes effective only after sufficient growth has occurred (28). Germ tube formation and subsequent mycelium growth of $P$. nicotianae were uninhibited in three separate amended agar trials employing a zoospore suspension rather than mycelium plugs (J. M. Kuhajek, unpublished data), and zoospore germination was unaffected by metalaxyl concentrations up to $600 \mu \mathrm{g} / \mathrm{ml}$ (51), indicating that metalaxyl is ineffective against germinating zoospores. Similarly, etridiazole has limited efficacy against germinating spores because it acts through inhibition of mitochondrial respiration by blocking electron transport between cytochromes b and c (45). However, when the etridiazole is present in sublethal concentrations, an alternative electron transport pathway using ubiquinone can be activated, allowing an isolate to appear to be tolerant of high etridiazole concentrations (30).

Sensitivity levels of $P$. nicotianae to copper hydroxide, fosetyl$\mathrm{Al}$, and propamocarb in the microbioassay generally were consistent with previously published results. Copper compounds, including copper hydroxide, act as enzyme poisons (20) and are highly toxic to Phytophthora spp. (29). Copper, in the form of copper oxide, was found to inhibit both mycelium growth and zoospore germination of $P$. palmivora at less than $100 \mu \mathrm{g} / \mathrm{ml}$ (53). In contrast to the general toxicity of copper compounds, fosetyl-Al selectively inhibits mycelium growth through effects on amino acid metabolism (49). Matheron and Porchas (37) found an $\mathrm{EC}_{50}$ value of $31 \mu \mathrm{g} / \mathrm{ml}$ for inhibition of mycelium growth of $P$. nicotianae by fosetyl-Al, whereas Farih et al. (23) reported a value of $929 \mu \mathrm{g} / \mathrm{ml}$ and Guest (29) reported an intermediate value of $140 \mu \mathrm{g} / \mathrm{ml}$. Propamocarb is relatively ineffective against zoospore germination $(7,29)$ but is moderately inhibitory to mycelium growth and severely retards germ tube formation (46). Guest (29) reported 14 to $96 \%$ inhibition of mycelium growth by $P$. nicotianae at $100 \mu \mathrm{g} / \mathrm{ml}$, depending on the growth medium employed.

Based on the combined results for all antifungal compounds evaluated in this study, an $\mathrm{EC}_{50}$ value of $200 \mu \mathrm{g} / \mathrm{ml}$ in the microbioassay appears to be an appropriate threshold to identify a compound with potential inhibitory activity against Phytophthora spp. and, therefore, worthy of secondary testing. With the exception of metalaxyl and etridiazole, all the fungicides tested with established efficacy against Phytophthora spp. exhibited $\mathrm{EC}_{50}$ values that were less than $200 \mu \mathrm{g} / \mathrm{ml}$. As with many in vitro bioassays, however, results obtained using the microbioassay may not always correlate to in vivo efficacy, especially because members of Phytophthora have numerous life stages, each with different susceptibility to fungicides (20). The assay does not detect inhibitory activity of compounds that do not inhibit spore germination (e.g., metalaxyl and etridiazole). As with any aqueous-based assay, including agar amendment, analysis of highly hydrophobic compounds (e.g., PCNB) also can be problematic because precipitation can interfere with analysis of growth. Filtration of opacuous suspensions through a membrane filter prior to the addition of zoospores should help to alleviate this problem. Regardless of whether filtration is used, however, results from insoluble compounds are qualitative at best and should not be used in quantitative calculations.

Despite some limitations, the advantages of a microbioassay for Phytophthora spp. are numerous. Growth medium and test compound requirements for the microtiter assay are approximately 20-

TABLE 3. Comparison of a new microtiter bioassay (MT) and the standard agar amendment assay (AA) for determining toxicity of antifungal compounds to three isolates of Phytophthora nicotianae (AF016, D003, and D119)

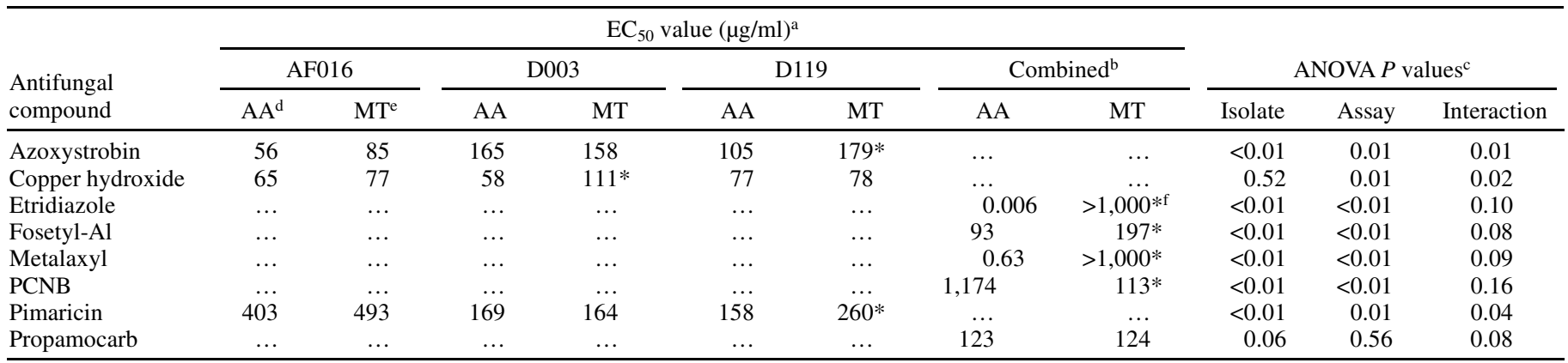

${ }^{\mathrm{a}} \mathrm{EC}_{50}$ value is the effective concentration of an antifungal compound that inhibited mycelium growth by $50 \%$ relative to a control. $*$ indicates that $\mathrm{EC}_{50}$ values predicted by the two assays were significantly different $(P \leq 0.05)$ based on unpaired $t$ tests.

b When isolate-assay interactions were not significant $(P>0.05)$, data for the three isolates were combined.

${ }^{c} P$ values from a two-way analysis of variance (ANOVA) for each fungicide with isolate as a random factor and assay fixed; degrees of freedom $=2,1$, and 2 for isolate, assay, and interaction, respectively.

${ }^{\mathrm{d}}$ Results were obtained by measuring radial growth of mycelium from an agar plug on chemical-amended agar. Data are the pooled means from two experiments conducted in time.

e Results were obtained by measuring optical density in a liquid medium at $620 \mathrm{~nm}$. Data are the pooled means from six experiments conducted in time.

${ }^{\mathrm{f}}$ Value indicates that less than $50 \%$ inhibition of growth was detected at the highest concentration tested. 
fold less than those for traditional methods like the agar amendment assay. Consequently, evaluation of natural products and other samples with limited availability - those available in milligram to microgram quantities - is feasible (32). Furthermore, laboratory space requirements to conduct the microbioassay are greatly reduced, and with the aid of multiwell pipettors, highthroughput screening is possible. For maximum reproducibility, the assay employs a buffered, $\mathrm{pH}$-adjusted, defined medium and standardized methods for preparation of zoospore suspensions. Photometric evaluation provides unbiased, automated three-dimensional analysis of mycelium growth. In addition, the microtiter format provides an opportunity to conduct mechanism-of-action studies for compounds of interest as well as rapid and efficient evaluation of multiple isolates.

\section{ACKNOWLEDGMENTS}

We thank L. Robertson for technical assistance, P. Pace for statistical support, and A. W. Douglas, D. Gibson, R. P. Kaiser, and two anonymous reviewers for valuable editorial suggestions. This research is part of a Ph.D. undertaken by J. Kuhajek.

\section{LITERATURE CITED}

1. Agrios, G. N. 1997. Plant Pathology. 4th ed. Academic Press, San Diego, CA.

2. Ann, P. J., and Ko, W. H. 1990. Growth rate and colony morphology of progenies of zoospores and selfed oospores of Phytophthora parasitica. Mycologia 82:693-697.

3. Berkson, J. 1951. Why I prefer logits to probits. Biometrics 7:327-339.

4. Boesewinkel, H. J. 1976. Storage of fungal cultures in water. Trans. Br. Mycol. Soc. 66:183-185.

5. Brockaert, W. F., Terras, F. R. G., Cammue, B. P. A., and Vanderleyden, J. 1990. An automated quantitative assay for fungal growth inhibition. FEMS Microbiol. Lett. 69:55-60.

6. Bruin, G. C. A., and Edgington, L. V. 1983. The chemical control of diseases caused by zoosporic fungi, a many sided problem. Pages 193-233 in: Zoosporic Plant Pathogens: A Modern Perspective. S. T. Buczacki, ed. Academic Press, London, UK.

7. Chan, L. G., and Kwee, L. T. 1986. Comparative in vitro sensitivity of selected chemicals on Phytophthora palmivora from Cocoa and Durian. Pertanika 9:183-191.

8. Chatterjee, S., and Price, B. 1991. Regression Analysis by Example. 2nd ed. John Wiley \& Sons, New York.

9. Chen, D. W., and Zentmyer, G. A. 1970. Production of sporangia by Phytophthora cinnamomi in axenic culture. Mycologia 62:397-402.

10. Coffey, M. D., Klure, L. J., and Bower, L. A. 1984. Variability in sensitivity to metalaxyl of isolates of Phytophthora cinnamomi and $P$. citricola. Phytopathology 74:417-422.

11. Davidse, L. C., and de Waard, M. A. 1984. Systemic fungicides. Pages 191-257 in: Advances in Plant Pathology, vol. 2. D. S. Ingram and P. H. Williams, eds. Academic Press, New York.

12. Davidse, L. C., Gerritsma, O. C. M., Ideler, J., Pie, K., and Velthuis, G. C. M. 1988. Antifungal modes of action of metalaxyl, cyprofuram, benalaxyl and oxadixyl in phenylamide-sensitive and phenylamide-resistant strains of Phytophthora megasperma f. sp. medicaginis and Phytophthora infestans. Crop Prot. 7:347-355.

13. Davidse, L. C., Hofman, A. E., and Velthius, G. C. M. 1983. Specific interference of metalaxyl with endogenous RNA polymerase activity in isolated nuclei from Phytophthora megasperma f. sp. medicaginis. Exp. Mycol. 7:344-361.

14. Davidse, L. C., Looijen, D., Turkensteen, L. J., and Van der Wal, D. 1981. Occurrence of metalaxyl-resistant strains of Phytophthora infestans in Dutch potato fields. Neth. J. Plant Pathol. 87:65-68.

15. Davidse, L. C., van den Berg-Velthius, G. C. M., Mantel, B. C., and Jespers, A. B. K. 1991. Phenylamides and Phytophthora. Pages 349-360 in: Phytophthora. J. A. Lucas, R. C. Shattock, D. S. Shaw, and L. R. Cooke, eds. British Mycological Society, Cambridge, UK.

16. Duan, C.-H., and Jeffers, S. N. 2001. Sensitivity to mefenoxam among isolates of Phytophthora cinnamomi and P. nicotianae from ornamental crops. (Abstr.) Phytopathology 91(suppl.):S24.

17. Duniway, J. M. 1983. Role of physical factors in the development of Phytophthora diseases. Pages 175-187 in: Phytophthora: Its Biology, Taxonomy, Ecology, and Pathology. D. C. Erwin, S. Bartnicki-Garcia, and P. H. Tsao, eds. The American Phytopathological Society, St. Paul, $\mathrm{MN}$.
18. Eckert, J. W., and Tsao, P. H. 1960. A preliminary report on the use of pimaricin in the isolation of Phytophthora spp. from root tissues. Plant Dis. Rep. 44:660-661.

19. Eckert, J. W., and Tsao, P. H. 1962. A selective antibiotic medium for isolation of Phytophthora and Pythium from plant roots. Phytopathology 52:771-777.

20. Erwin, D. C., and Ribeiro, O. K. 1996. Phytophthora Diseases Worldwide. The American Phytopathological Society, St. Paul, MN.

21. Espinel-Ingroff, A., Dawson, K., Pfaller, M., Anaissie, E., Breslin, B., Dixon, D., Fothergill, A., Paetznick, V., Peter, J., Rinaldi, M., and Walsh, T. 1995. Comparative and collaborative evaluation of standardization of antifungal susceptibility testing for filamentous fungi. Antimicrob. Agents Chemother. 39:314-319.

22. Espinel-Ingroff, A., and Kerkering, T. M. 1991. Spectrophotometric method of inoculum preparation for the in vitro susceptibility testing of filamentous fungi. J. Clin. Microbiol. 29:393-394.

23. Farih, A., Tsao, P. H., and Menge, J. A. 1981. Fungitoxic activity of efosite aluminum on growth, sporulation, and germination of Phytophthora parasitica and P. citrophthora. Phytopathology 71:934-936.

24. Farih, A., Tsao, P. H., and Menge, J. A. 1981. In vitro effects of metalaxyl on growth, sporulation, and germination of Phytophthora parasitica and $P$. citrophthora. Plant Dis. 65:651-654.

25. Ferrin, D. M., and Kabashima, J. N. 1991. In vitro insensitivity to metalaxyl of isolates of Phytophthora citricola and P. parasitica from ornamental hosts in Southern California. Plant Dis. 75:1041-1044

26. Gisi, U., and Schwinn, F. J. 1976. The suitability of vital stains and optical brighteners to fluorescent microscopical observation of Phytophthora cactorum (Leb. et Cohn) Schroet. in vitro and in soil. Micron Microsc. Acta 77:402-419.

27. Goodwin, J. R., Anthony, V. M., Clough, J. M., and Godrey, C. R. A. 1992. ICIA-5504: A novel, broad spectrum, systemic $\beta$-methoxyacrylate fungicide. Pages 435-442 in: Proc. Br. Crop Prot. Conf. Pests Dis. 1992. Vol. 1.

28. Grohmann, U. J., and Hoffmann, G. M. 1989. Leaf infection and tissue colonization in potato plants by Phytophthora infestans influenced by increasing dosages of metalaxyl. Z. Pflanzenkr. Pflanzenschutz 96:585603.

29. Guest, D. I. 1984. The influence of cultural factors on the direct antifungal activities of fosetyl-Al, propamocarb, metalaxyl, SN 75196 and Dowco 444. Phytopathol. Z. 111:155-164.

30. Halos, P. M., and Huisman, O. C. 1976. Mechanism of tolerance of Pythium species to ethazol. Phytopathology 66:152-157.

31. Hendrix, J. W. 1970. Sterols in growth and reproduction of fungi. Annu. Rev. Phytopathol. 8:111-130.

32. Kuhajek, J. M. 2001. Variability in the antifungal activity of wetland plants and implications to natural products research. Ph.D. diss. University of Mississippi, University.

33. Lamour, K. H., and Hausbeck, M. K. 2000. Mefenoxam insensitivity and the sexual stage of Phytophthora capsici in Michigan cucurbit fields. Phytopathology 90:396-400.

34. Lazarovitis, G. 1985. Influence of pyroxyfur seed treatment, inoculum density, and low level cultivar resistance on Phytophthora megasperma f. sp. glycinea rot of soybean. Can. J. Plant Pathol. 7:370-376.

35. Luo, L., Ho, H. H., and Jong, S. C. 1988. Study on the physiological characteristics of the genus Phytophthora. Mycotaxonomy 32:199-217.

36. Macris, B., and Georgopoulos, S. G. 1969. Reduced hexosamine content of fungal cell wall due to the fungicide, pentachloronitrobenzene. Phytopathology 59:879-880.

37. Matheron, M. E., and Porchas, M. 2000. Impact of azoxystrobin, dimethomorph, fluazinam, fosetyl-Al, and metalaxyl on growth, sporulation, and zoospore cyst germination of three Phytophthora spp. Plant Dis. 84:454-458.

38. National Committee for Clinical Laboratory Standards (NCCLS). 1997. Reference method for broth dilution antifungal susceptibility testing of yeasts; approved standard. NCCLS Doc. M27-A. NCCLS 17:1-11.

39. National Committee for Clinical Laboratory Standards (NCCLS). 1998. Reference method for broth dilution antifungal susceptibility testing of conidium-forming filamentous fungi; proposed standard. NCCLS Doc. M38-P. NCCLS 18:1-20.

40. Ocaña, G. 1967. Relation of sterols to the differential sensitivity of spores and mycelia of Phytophthora to polyene antibiotics. Ph.D. diss. University of California, Riverside.

41. Parra, G. P., and Ristaino, J. B. 1998. Insensitivity to Ridomil Gold (mefenoxam) found among field isolates of Phytophthora capsici causing Phytophthora blight on bell peppers in North Carolina and New Jersey. Plant Dis. 82:711.

42. Paxton, J. D. 1991. Assays for antifungal activity. Pages 33-46 in: Methods in Plant Biochemistry, vol. 6. K. Hostettmann, J. B. Harborne, and P. M. Dey, eds. Academic Press, London, UK. 
43. Pennisi, A. M., Agosteo, G. E., Cacciola, S. O., Pane, A., and Faedda, R. 1998. Insensitivity to metalaxyl among field isolates of Phytophthora capsici causing root and crown rot of pepper in southern Italy. Plant Dis. 82:1283.

44. Pfaller, M. A., Burmeister, L., Barlett, M. S., and Rinaldi, M. G. 1988. Multicenter evaluation of four methods of yeast inoculum preparation. J. Clin. Microbiol. 26:1437-1441.

45. Radzuhn, B., and Lyr, H. 1984. On the mode of action of the fungicide etridiazole. Pestic. Biochem. Physiol. 22:14-23.

46. Reiter, B., Wenz, M., Buschhaus, H., and Buchenauer, H. 1996. Action of propamocarb against Phytophthora infestans causing late blight of potato and tomato. Pages 147-156 in: Fungicides and Antifungal Compounds: 11th International Symposium. H. Lyr, P. E. Russell, and H. D. Sisler, eds. Intercept Press, Andover, England.

47. Schwinn, F. J. 1979. Control of Phycomycetes: A changing scene. Pages 791-802 in: Proc. Br. Crop Prot. Conf. Pests Dis. 1979. Vol. 3.

48. Schwinn, F. J., and Staub, T. 1987. Phenylamides and other fungicides against Oomycetes. Pages 259-273 in: Modern Selective Fungicides: Properties, Applications, Mechanisms of Action. H. Lyr, ed. Longman Scientific and Technical, London.

49. Schwinn, F. J., and Staub, T. 1995. Oomycetes fungicides. Pages 323346 in: Modern Selective Fungicides: Properties, Applications, Mechanisms of Action. 2nd ed. H. Lyr, ed. Gustav Fischer Verlag, Jena,
Germany.

50. Sokal, R. R., and Rohlf, F. J. 1989. Introduction to Biostatistics. 2nd ed. W. H. Freeman \& Co., New York.

51. Staub, T. H., and Young, T. R. 1980. Fungitoxicity of metalaxyl against Phytophthora parasitica var. nicotianae. Phytopathology 70:797-801.

52. Steinhausen, W. R. 1979. On the importance of plant pathogenic organisms assessed by literature studies. Z. Pflanzenkr. Pflanzenschutz 86:86-92.

53. Tey, C. C., and Wood, R. K. S. 1983. Effects of various fungicides in vitro on Phytophthora palmivora from cocoa. Trans. Br. Mycol. Soc. 80:271-282.

54. Tsao, P. H. 1970. Selective media for isolation of pathogenic fungi. Annu. Rev. Phytopathol. 8:157-186.

55. Tsao, P. H., and Ocaña, G. 1969. Selective isolation of species of Phytophthora from natural soils on an improved antibiotic medium. Nature (London) 223:636-638.

56. Verpoorte, R. 1998. Exploration of nature's chemodiversity: The role of secondary metabolites as leads in drug development. Drug Discovery Today 3:232-238.

57. Wedge, D. E., and Kuhajek, J. M. 1998. A microbioassay for fungicide discovery. South. Assoc. Agric. Sci. Bull. Biochem. Biotechnol. 11:1-7.

58. Yourman, L. F., and Jeffers, S. N. 1999. Resistance to benzimidazole and dicarboximide fungicides in greenhouse isolates of Botrytis cinerea. Plant Dis. 83:569. 